\title{
Olahan kelapa dan singkong untuk kemajuan desa pematang tujuh kecamatan rasau jaya kalimantan barat
}

\author{
Coconut and Singkong Process for The Progress of The Villager of Pematang Tujuh \\ Sub-district Rasau Jaya, West Kalimantan \\ Agato $^{1)}$, Kardison Lumban Batu ${ }^{1)}$ \\ ${ }^{1}$ Politeknik Negeri Pontianak, Jurusan Teknologi Pertanian dan Administrasi Bisnis, Jalan \\ Jenderal Ahmad Yani Pontianak, Kalimantan Barat
}

Informasi Artikel:

Dikirim: 05/09/2019; ditinjau: 06/09/2019; disetujui: 30/09/2019

\begin{abstract}
Coconut and cassava are known as multi-functional plants that can be processed into various food and non-food preparations. In food processing using coconut using water and fruit flesh into a variety of food preparations that have economic value, while cassava can be used for tubers and parts of the skin. The processing of coconuts and cassava is aimed at farmer groups in Pematang Tujuh village, Rasau Jaya District, West Kalimantan. The purpose of this activity is the formation of a diversified group of coconut and cassava based products, so that work partners have an entrepreneurial spirit as measured by the formation of a small business group of processed coconut and cassava products, as well as having the ability to open market share and form new marketing networks. The method used is to begin with the delivery of information on opportunities that might be created from the local potential of Pematang Tujuh village and the guidance of new business management to achieve the success of the proposed program. This is followed by a comprehensive processing and management system for various processed coconut and cassava starting from the production, operation of machines and equipment, storage packaging systems and a complete management system for opening new businesses. The results obtained are all participants can do the processing of products from coconut and cassava.
\end{abstract}

Keywords: coconut, cassava, service, processed products

\begin{abstract}
ABSTRAK
Kelapa dan singkong dikenal sebagai tanaman multi fungsi yang dapat diolah menjadi berbagai olahan pangan dan non pangan. Pada pengolahan pangan menggunakan kelapa memanfaatkan air dan daging buah menjadi ragam olahan pangan yang memiliki nilai ekonomis, sedangkan pada olahan singkong dapat digunakan umbi dan bagian kulit. Pengolahan kelapa dan singkong ini ditujukan bagi kelompok tani desa Pematang Tujuh Kecamatan Rasau Jaya Kalimantan Barat. Tujuan kegiatan ini adalah terbentuknya kelompok diversivikasi produk berbasis kelapa dan singkong, sehingga mitra kerja memiliki jiwa kewirausahaan yang diukur dengan terbentuknya kelompok usaha kecil produk olahan kelapa dan singkong, serta memiliki kemampuan dalam membuka pangsa pasar dan membentuk jaringan pemasaran baru. Metoda yang digunakan adalah dengan dengan penyampaian informasi terhadap peluang yang mungkin dapat diciptakan dari potensi lokal yang dimiliki Desa Pematang Tujuh serta pembimbingan terhadap manajemen usaha baru untuk mencapai kesuksesan progam yang di canangkan. Selanjutnya diikuti dengan sistem dan tata kelola pengolahan aneka
\end{abstract}


olahan kelapa dan singkong secara menyeluruh yang dimulai dari produksi, pengoperasionalan mesin dan peralatan, sistem pengemasan penyimpanan dan sistem manajemen yang utuh tentang pembukaan usaha baru. Hasil yang diperoleh adalah seluruh peserta dapat melakukan tata olah produk dari kelapa dan singkong.

Kata Kunci: kelapa, singkong, pengabdian, olahan produk

\section{PENDAHULUAN}

Rasau Jaya merupakan daerah tujuan transmigrasi yaitu penempatan pada tahun 1991 yang merupakan kecamatan di wilayah Kabupaten Kubu Raya Propinsi Kalimantan Barat. Kabupaten Kubu Raya merupakan Kabupaten baru pemekaran Kabupaten Pontianak yang dilaksanakan pada tahun 2007. Desa Pematang Tujuh merupakan desa yang berada di dataran rendah dengan ketinggian tanah dari permukaan laut sebesar 0,5-1,5 M, suhu udara rata-rata $28^{\circ} \mathrm{C}$ dengan curah hujan $3.175 \mathrm{Mm} /$ tahun serta memiliki batasan wilayah yaitu Sebelah Utara berbatasan dengan Desa Punggur Keci Kecamatan Sungai Kakap, sebelah Selatan bebatasan dengan Sungai Punggur kecamatan Teluk Pakedai, sebelah Barat berbatasan dengan Punggur Besar kecamatan sungai Kakap dan sebelah Timur berbatasan dengan desa Bintang Mas Kecamatan Rasau jaya (BPS Kabupaten Kubu Raya, 2014) dengan jarak tempuh $\pm 28,9 \mathrm{~km}$ dari Politekinik Negeri Pontianak dengan waktu tempuh \pm 2 jam.

Transportasi yang dapat digunakan adalah transportasi darat dengan kondisi jalan mengalami banyak kerusakan. Komoditi lokal Desa Pematang Tujuh adalah kelapa, jagung dan singkong.Kelapa dikembangkan sebagai tanaman perkebunan. Pada tahun 2015 luas kebun kelapa dalam adalah 9.857 ha dengan produksi 7.077 ton, luas kebun kelapa hibrida 2.961 ha dengan produksi 1.559 ton (Buku data dan informasi KTM Rasau Jaya, 2016). Singkong merupakan tanaman perkarangan yang ditanam masyarakat Desa Pematang Tujuh. Komoditi lokal hasil pertanian ini biasa dijual dalam bentuk segar dipasar-pasar sekitar Rasau Jaya dan kekota Pontianak seperti pasar Flamboyan, pasar Dahlia dan lainnya. Melemahnya harga jual kelapa menyebabkan berkurangnya motivasi pengembangan kelapa, sehingga cukup banyak petani yang mulai meninggalkan usaha kelapa. Menurunnya nilai jual produk olahan setengah jadi berupa kopra yang menjadi andalan petani memperpaarh kondisi petani kelapa. Untuk pengembangan pertanian, petani di Desa Pematang Tujuh telah membentuk gabungan kelompok tani (Gapoktan). Gapoktan ini dibentuk sebagai wadah diskusi masyarakat petani dalam pengembangan pertanian, kelompok untuk bekerja sama dalam mengolah lahan dan kegiatan sosial lainnya.

Sasaran kegiatan pengabdian kepada masyarakat (PKM) ini adalah kelompok tani yang aktif berkegiatan dan berkelanjutan. Komoditi kelapa dan singkong adalah komoditi lokal Desa Pematang Tujuh yang dapat dikembangkan menjadi produk pangan yang berkualitas. Kelapa dikenal sebagai tanaman multi fungsi mulai dari batang, buah hingga daun kelapa. Menurut Sindumathi dan Amutha (2014), sebagai makanan fungsional, kelapa memiliki lemak asam yang menyediakan energi dan bahan baku untuk aktivitas antimikroba dan monogliserida. asam laurat, yang utama hadir asam lemak dalam kelapa. Air kelapa adalah sumber makanan kaya sitokinin. Mengkonsumsi makanan yang kaya sitokinin, seperti air kelapa, bisa menghasilkan efek anti-penuaan pada tubuh, mengurangi risiko mengembangkan penyakit degeneratif dan usia terkait (Alleyne, 2005). Produk pangan yang dapat diolah dari bahan kelapa dapat berupa kecap air kelapa, sirup kelapa dan kelapa kering dan selai kelapa.

Pohon kelapa memiliki peranan penting peran dalam mobilitas manusia di berbagai geografis wilayah dunia sebagai sumber makanan, air, dan berbagai kegunaan lainnya (Loiola et al., 2016), dikatakan tak tertandingi dalam kerajaan tumbuhan (Gunn, 
Baudouin, \& Olsen, 2011). Air kelapa segar adalah minuman menyegarkan dan bergizi biasanya diekstrak dari kelapa yang belum matang dari usia 6-9 bulan (Rolle, 2007). Ini disebabkan oleh kenyataan bahwa sebagai kelapa menghasilkan komposisi dan sifat fisikokimia alter, dengan kernel putih lapisan kulit bagian dalam menjadi buram dan mengeras. Sedangkan kelapa air mengalami perubahan dalam rasio gula, juga peningkatan $\mathrm{pH}$, kekeruhan dan kandungan mineral dengan hilangnya rasa dan kualitas (Tan et al., 2014). Kandungan nutrisi kelapa air juga menjadi pusat beberapa penelitian (Santoso et al., 1996).

Buah kelapa sangat bermanfaat bagi kesehatan (DebMandal \& Mandal, 2011), efektivitasnya (Kalman, Feldman, Krieger, \& Bloomer, 2012), atau tidak (Peart, Hensby, \& Shaw, 2017), sebagai minuman energi olahraga, kandungan vitamin $\mathrm{B}$ dan $\mathrm{C}$, pengobatan hipertensi (Bhagya, Prema dan Rajamohan, 2012) dan kolesterol tinggi, hingga banyak diklaimsifat medis termasuk efek hipoglikemik dan antioksidan (Bispo et al., 2017), serta antimikroba (Mandal et al., 2009), antivirus, antiparasit, antidermatofit, hepatoprotektif, dan imunostimulan properti (DebMandal dan Man dal, 2011).

Tanaman singkong adalah sumber utama pati (Sanchez et al., 2009) dan akarnya dapat dikonsumsi segar atau diolah menjadi beberapa produk makanan komposit. Singkong sangat penting untuk ketahanan pangan karena dapat dipanen sepanjang tahun, tumbuh baik dengan input minimum, mudah disebarkan menggunakan stek batang dan beradaptasi dengan baik untuk sejumlah lingkungan yang keras (Ogola dan Mathews, 2011; Burns et al., 2012).

Singkong (Manihot esculanta L) menjadi bahan pangan pokok setelah beras dan jagung di Indonesian. Singkong merupakan sumber karbohidrat yang juga mengandung protein, $\mathrm{Ca}, \mathrm{B} 1, \mathrm{~B} 2$, Vitamin $\mathrm{C}$ dan kalori (Chan, 1983). Proses ektraksi singkong relatif lebih mudah karena mengandung protein dan lemak yang rendah dan jika diproses dengan baik, akan dihasilkan pati yang bersih dan putih yang dapat diaplkasikan dalam pembuatan kue (Moorthy, 2004). Singkong terdiri dari daging singkong dan 15-20\% berupa kulit yang dianggap sebagai limbah. Kulit singkong bagian dalam yang dianggap sebagai limbah masih mengandung nutrisi seperti serat kasar, Ca dan Protein sehingga layak diolah menjadi produk pangan (Arifin, 2005). Kulit singkong yang dikeringkan dapat diolah menjadi tepung (Rukmana, 1997). Usaha untuk dapat mengolah singkong menjadi produk pangan berupa rengginang singkong, cake dan sambal goreng kulit singkong serta olahan kelapa menjadi produk pangan kecap air kelapa, sirup kelapa dan kelapa kering dan selai kelapasangat diharapkan oleh masyarakat Desa Pematang Tujuh yang ingin diwujudkan oleh tim kegiatan PKM Pengembangan Desa Pematang Tujuh dalam kreatifitas olah pangan dari singkong dan kelapa.

Rendahnya pengetahuan masyarakat Desa Pematang Tujuh tentang kandungan gizi pada singkong dan kelapa yang dapat dimanfaatkan sebagai produk pangan serta minimnya ketrampilan dalam mengolah komoditi lokal berupa singkong dan kelapa menjadi masalah utama masyarakat Desa Pematang Tujuh. Kondisi tersebut tercermin dari Isu dibidang Sumber Daya Manusia (SDM) dalam Rencana Pembangunan Jangka Menengah (RPJM) yang menjelaskan bahwa rendahnya kualitas SDM ini terutama disebabkan masih terbatasnya akses terhadap pendidikan.

Bercermin dari analisis isu-isu strategis bidang ekonomi yang dicanangkan Bapeda kabupaten Kubu Raya, yaitu peningkatan ekonomi masyarakat sejalan dengan peningkatan kualitas SDM menjadi isu yang terpenting.

\section{METODA PELAKSANAAN}

Kegiatan Pengabdian masyarakat ini dilakukan Kantor Desa Pematang Tujuh , hal ini dimaksudkan agar semua peserta dapat dengan mudah mengakses lokasi 
berkumpul. Kegiatan ini dihadiri 10 orang peserta.

Bahan yang digunakan dalam pengolahan aneka produk makanan terdiri dari kelapa dansingkong yang kami peroleh dari warga setempat, sedangkan bahan-bahan untuk pembuatan produk yaitu: 1) sirup kelapa: air kelapa muda, gula, garam, vanilla, pewarna dan daun pandan. 2)selai kelapa: daging buah kelapa muda, gula, garam, daun pandan, roti tawar. 3) Kecap air kelapa: air kelapa tua, gula merah dan bumbu-bumbu. 4) Rengginang singkong: singkong, garam, gula, merica,bumbu, bawang putih dan minyak goring. 5) Sambal kulit singkong: kulit singkong, bumbu-bumbu, minyak goring.

Alat yang digunakan untuk pengolahan produk meliputi: kuali, panci perebusan,pengukus, sendok, gelas dan cup plastic, kompor gas, baskom bolong,blender, seller, pisau, timbangan, sutil, wadah kemas, baskom besar baskom keci, plastic kemasan, plastik PE, spatula, serbet, tissue, teko ukur, cetakan rengginang, kertas minyak, nampan , tabung gas, botol kecap.

Aspek Proses Produksi Olahan.

\section{Sirup kelapa}

Siapkan air kelapa muda dan disaring untuk menghilangkan kotoran yang terikut, kemudian ditambahkan gula pasir, pewarna, vanili dan daun pandan, kemudian dimasak hingga mencapai suhu $80^{\circ} \mathrm{C}$. Proses selanjutnya didinginkan dan dimasukkan kedalam cup dan botol sirup dan diberikan label produk.

\section{Selai sirup}

Siapkan daging kelapa muda dan dihaluskan dengan blender selama 15 menit, kemudian ditambahkan gula, garam, vanili dan daun pandan, kemudian masak larutan tersebut hingga mencapai konsistensi selai, setelah dingin selai yang diperoleh kemudian di masukkan dalam cup dan diberikan label produk.

\section{Kecap air kelapa}

Siapkan air kelapa tua disaring untuk menghilangkan kotoran, tambahkan bumbu bumbu yang telah disediakan dan masak hingga 1 jam dan mendekati konsistensi kecap.Setelah matang lakukan penyaringan, hasil filtrate yang diperoleh kemudian dikemas dalam botol dan diberikan label produk.

\section{Rengginag singkong}

Menyiapkan singkong untuk dikupas dan dibersihkan dari kotoran yang tidak dapat dimakan, selanjutnya diparut secara kasar. Hasil parutan kemudian diperasdan ampas yang diperoleh kemudian ditambahkan bumbu dan dilakukan pencetakan. Hasil cetakan yang diperoleh kemudian dikukus selama 10 menit dan setelahnya hasil kukusan dijemur hingga kering yaitu 3 hari.Hasil rengginang kering kemudian digoreng dan ditambahkan bumbu aneka rasa, dikemas dan diberikan label produk.

\section{Sambal goreng kulit ubi}

Kulit ubi yang berwarna putih kemudian dicuci dan direndam dengan air garam, selanjutnya diiris tipis-tipis. Hasil irisan kemudian dicuci dengan air mengalir dan ditiriskan dan digoreng hingga kuning keemasan.Pada bagian lain siapkan bumbubumbu berupa cabe rawit, tomat dan bawang putih untuk dihaluskan. Tumis bumbu hingga harum dan matang setelah matang masukan irisan kulit ubi dan ikan teri halus yang telah digoreng. Setelah dingin kemudian dikemas dalam cup sambal goring dan diberikan label.

\section{HASIL DAN PEMBAHASAN}

Hasil produk yang dihasilkan, kemudian dilakukan uji penerimaan konsumen terbatas pada seluruh peserta pelatihan dengan jumlah responden 10 orang. Hasil yang diperoleh terhadap olahan produk disajikan pada Tabel 1. 
Tabel 1. Olahan produk talas dan jagung

\begin{tabular}{lcc}
\hline Nama Produk & \multicolumn{2}{c}{ Penilaian Konsumen } \\
\cline { 2 - 3 } & Menerima & Tidak Menerima \\
\hline Sirupkelapa & 10 & 0 \\
Selaikelapa & 10 & 0 \\
Kecap air kelapa & 5 & 5 \\
Rengginang Singkong & 10 & 0 \\
Sambal Kulit Singkong & 10 & 0 \\
\hline
\end{tabular}

Sumber data: Kuisioner kegiatan PKM 2019 Desa Pematang Tujuh

\section{Sirup kelapa}

Sirup kelapa yang dihasilkan pada kegiatan ini berwarna hijau, berasa manis dan memiliki tekstur kental. Berdasarkan jumlah responden sebanyak 10 orang, maka memberikan penilaian suka artinya seluruh responden (100\%) menyukai sirup yang dihasilkan. Sama halnya dengan sirup yang dijual secara komersil, maka sirup air kelapa juga disajikan dengan cara menambahkan air putih untuk pengencerannya. Pengenceran dilakukan dengan tujuan untuk mengurangi tingkat kekentalan, kemanisan dan warna yang dihasilkan.

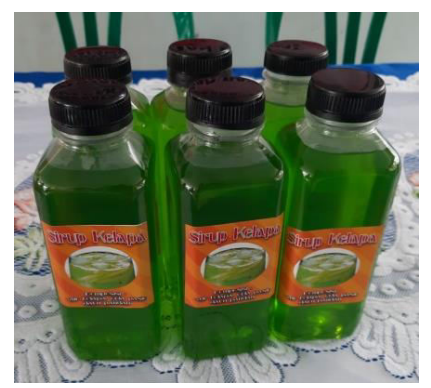

Gambar 1. Sirup kelapa

\section{Selai kelapa}

Selai merupakan produk makanan tambahan yang digunakan untuk dioleskan pada permukaan roti. Produk ini memiliki konsistensi yang kental, berasa manis, warna yang cerah dan transparan. Berdasarkan penyebaran data terhadap responden yang berjumlah 10 orang, maka semua menyukai produk yang selai yang dihasilkan. Alasan disukainya produk ini adalah karena selain metoda pengolahannya yang sederhana, juga memiliki rasa dan konsistensi yang hamper sama dengan selai pada umumnya. Menurut Trisnowati, (2012) selai merupakan produk makanan dengan konsisten gel atau semi padat yang di buat dari bubur buah. Konsistensi gel atau semi padat pada selai di peroleh dari senyawa pektin yang berasal dari buah atau pektin yang ditambahkan dari luar, gula sukrosa dan asam.Interaksi ini terjadi pada suhu tinggi dan bersifat menetap setelah suhu di turunkan. Kekerasan gel tergantung pada konsentrasi gula, pektin dan asam pada bubur

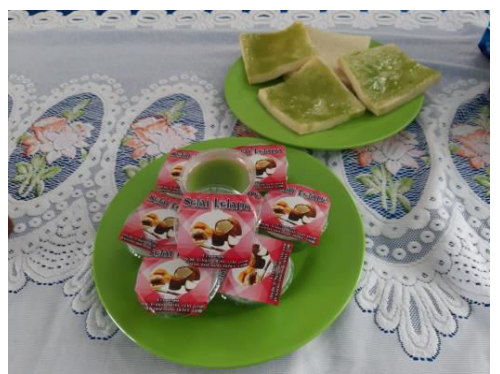

Gambar 2. Selai kelapa muda

\section{Kecap air kelapa}

Tidak semua respoden menyukai kecap air kelapa yang dihasilkan. Dari 10 responden maka 5 responden menyukai dan 5 responden tidak menukai. Menurut responden alasan menyukai produk kecap yang terbuat dari air kelapa tua disebabkan karena aroma khas yang dimiliki dan dapat mengatur tingkat kekentalan kecap yang diinginkan pada saat pengolahannya, sehingga dapat disesuaikan dengan yang diinginkan. Namun ketidak sukaan sebagian responden memiliki alasan bahwa rasa yang dihasilkan berbeda dengan kecap komersil pada umumnya. Secara umum kecap merupakan bumbu dapur atau penyedap makanan yang berupa cairan berwarna hitam yang rasanya manis atau asin dan bahan dasar pembuatan kecap umumnya adalah 
kedelai atau kedelai hitam (Haerani, Hamdana , 2016)

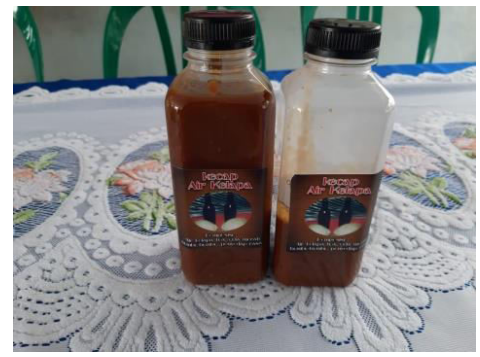

Gambar 3. Kecap air kelapa

\section{Rengginang singkong}

Berdasar hasil uji terhadap produk rengginang, maka $100 \%$ responden menyukai produk rengginang, Hal ini disebabkan karena rengginang singkong memiliki tekstur yang renyah, rasa yang gurih. Menurut responden rengginang singkong pembuatannya juga lebih mudah dan harganya yang murah.

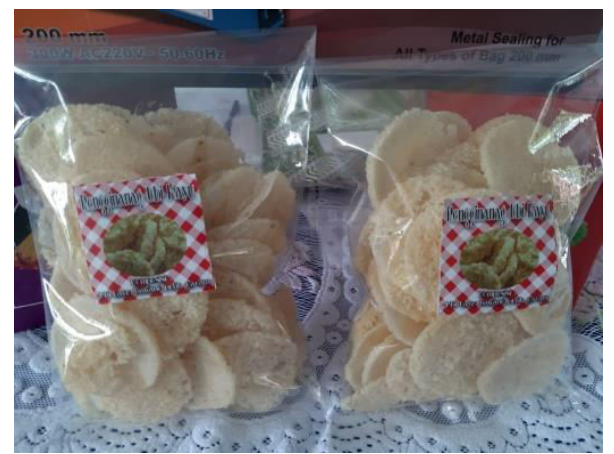

Gambar 4. Rengginang singkong

\section{Sambal keripik ubi}

Kulit ubi adalah bagian dari umbi yang umumnya tidak digunakan kembali, namun berdasarkan beberapa penelitian yang telah dilakukan kulit ubi mengandung serat yang baik untuk pencernaan, sehingga baik juga dikonsumsi oleh manusia. Berdasarkan penilaian responden, maka $100 \%$ responden menyukai produk yang dihasilkan, hal ini disebabkan karena tampilan, rasa dan warna yang menarik dan dapat meningkatkan selera makan bagi pengkonsumsinya. Kulit singkong Kandungan energi dan nutrisi yang dimiliki kulit singkong dalam 100 gram limbah kulit singkong adalah protein 8,11 gram, serat kasar 15,20 gram, pektin 0,22 gram, lemak 1,29 gram, kalsium 0,63 gram

dan menurut Rukmana (1997) kulit singkong mengandung zat gizi yang dapat dimanfaatkan untuk tubuh.

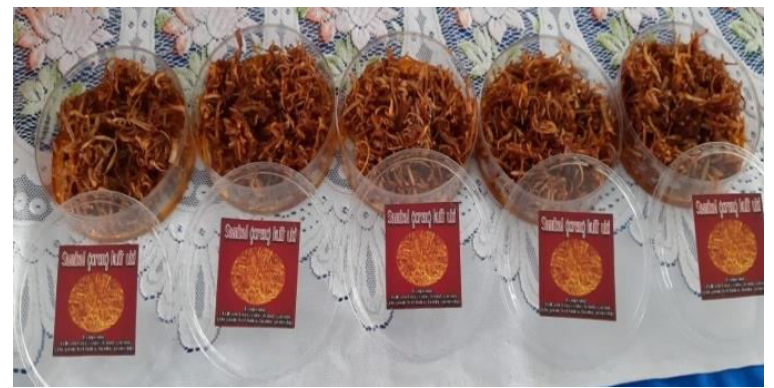

Gambar 5. Sambal goreng kulit ubi

\section{KESIMPULAN}

Berdasarkan penilaian yang dilakukan oleh responden maka produk sirup, selai, rengginang dan sambal goring kulit ubi kayu $100 \%$ disukai oleh responden, sedangkan kecap air kelapa hanya disukai 50\% dari total responden.

\section{UCAPAN TERIMAKASIH}

Tim pelaksana PKM mengucapkan terima kasih kepada Kemenristekdikti yang telah memberikan dana dalam pelaksanaan PKM 2019, politeknik negeri Pontianak membantu dalam pelaksanaan kegiatan PKM dan kelompok tani desa pematang tujuh sebagai mitra kegiatan PKM.

\section{DAFTAR PUSTAKA}

Alleyne, T. (2005). The control of hypertension by use of coconut water and mauby: two tropical food drinks. West Indian Med Journal, 54, 3-8

Arifin. (2005). Kandungan gizi pada ubi kayu. Jurnal Ilmu-Ilmu Peternakan, 9(2), 90-110

Bhagya, D., Prema, L., \& Rajamohan, T. (2012). Therapeutic effects of tender coconut water on oxidative stress in fructose fed insulin resistant hypertensive rats. Asian Pacific journal of tropical medicine, 5(4), 270276. 
Bispo, V. S., Dantas, L. S., Chaves Filho, A. B., Pinto, I. F., SILVA, R. P., Otsuka, F. A., .. \& Matos, H. R. (2017). Reduction of the DNA damages, hepatoprotective effect and antioxidant potential of the coconut water, ascorbic and caffeic acids in oxidative stress mediated by ethanol. Anais da Academia Brasileira de Ciências, 89(2), 1095-1109.

Burns, A. E., Gleadow, R. M., Zacarias, A. M., Cuambe, C. E., Miller, R. E., \& Cavagnaro, T. R. (2012). Variations in the chemical composition of cassava (Manihot esculenta Crantz) leaves and roots as affected by genotypic and environmental variation. Journal of Agricultural and Food Chemistry, 60(19), 4946-4956.

Chan, H. T. (1983). Handbook of tropical foods. Marcel Dekker Inc. New york and Bassel

DebMandal, M., \& Mandal, S. (2011). Coconut (Cocos nucifera L.: Arecaceae): in health promotion and disease prevention. Asian Pacific Journal of Tropical Medicine, 4(3), 241-247.

Gunn, B. F., Baudouin, L., \& Olsen, K. M. (2011). Independent origins of cultivated coconut (Cocos nucifera L.) in the old world tropics. Plos one, 6(6), e21143.

Haerani, H. (2016). Pengembangan kecap dari air kelapa. Seminar Nasional "Pendidikan Ilmu-Ilmu Sosial Membentuk Karakter Bangsa Dalam Rangka Daya Saing Global" Kerjasama: Fakultas Ilmu Sosial Universitas Negeri Makassar dan Himpunan Sarjana Pendidikan Ilmuilmu Sosial Indonesia Grand Clarion Hotel, Makassar

Kalman, D. S., Feldman, S., Krieger, D. R., \& Bloomer, R. J. (2012). Comparison of coconut water and a carbohydrateelectrolyte sport drink on measures of hydration and physical performance in exercise-trained men. Journal of the
International Society of Sports Nutrition, 9(1), 1.

Loiola, C. M., Azevedo, A. O. N., Diniz, L. E., Aragão, W. M., Azevedo, C. D. D. O., Santos, P. H. A., ... \& Ramos, S. R. R. (2016). Genetic relationships among tall coconut palm (Cocos nucifera L.) accessions of the International Coconut Genebank for Latin America and the Caribbean (ICG-LAC), evaluated using microsatellite markers (SSRs). PloS one, 11(3), e0151309.

Mandal, S. M., Dey, S., Mandal, M., Sarkar, S., Maria-Neto, S., \& Franco, O. L. (2009). Identification and structural insights of three novel antimicrobial peptides isolated from green coconut water. Peptides, 30(4), 633-637.

Moorthy. S. (2004). Tropical sources of starch. CRC Press. Baco Raton Florida

Ogola, J. B. O., \& Mathews, C. (2011). Adaptation of cassava (Manihot esculenta) to the dry environments of Limpopo, South Africa: growth, yield and yield components. African Journal of Agricultural Research, 6(28), 60826088.

Peart, D. J., Hensby, A., \& Shaw, M. P. (2017). Coconut water does not improve markers of hydration during sub-maximal exercise and performance in a subsequent time trial compared with water alone. International journal of sport nutrition and exercise metabolism, 27(3), 279-284.

Rukmana, R . (1997). Ubi kayu, budidaya dan pascapanen. Jakarta: Penerbit Kanisius.

Sánchez, T., Salcedo, E., Ceballos, H., Dufour, D., Mafla, G., Morante, N., ... \& Moreno, I. X. (2009). Screening of starch quality traits in cassava (Manihot esculenta Crantz). Starch-Stärke, 61(1), 12-19.

Santoso, U., Kubo, K., Ota, T., Tadokoro, T., \& Maekawa, A. (1996). Nutrient composition of kopyor coconuts (Cocos nucifera L.). Food Chemistry, 57(2), 299-304. 
Tan, T. C., Cheng, L. H., Bhat, R., Rusul, G., \& Easa, A. M. (2014). Composition, physicochemical properties and thermal inactivation kinetics of polyphenol oxidase and peroxidase from coconut (Cocos nucifera) water obtained from immature, mature and overly-mature coconut. Food Chemistry, 142, 121-128.

Trisnowati, N. (2012). Pembuatan selai apel (malus sylvestris mill). Hal.1-51. 